\title{
On the Socio-Cultural Determinants of Polish Entrepreneurs' Attitudes towards the Development of Renewable Energy: Business, Climate Skepticism Ideology and Climate Change
}

\author{
Piotr Żuk ${ }^{1,2, *(D)}$ and Paweł Żuk ${ }^{3}$ \\ 1 The Centre for Civil Rights and Democracy Research, 51-003 Wroclaw, Poland \\ 2 The Institute for Sustainable Development and Renewable Energy, 53-031Wroclaw, Poland \\ 3 Department of Sociology and Social Policy, Wroclaw University of Economics, 53-345 Wroclaw, Poland; \\ pawel.zuk@ue.wroc.pl \\ * Correspondence: piotr.zuk@protonmail.com
}

check for

updates

Citation: Żuk, P.; Żuk, P. On the Socio-Cultural Determinants of Polish Entrepreneurs' Attitudes towards the Development of Renewable Energy: Business, Climate Skepticism Ideology and Climate Change. Energies 2021, 14, 3418. https:// doi.org/10.3390/en14123418

Academic Editors: David Borge-Diez, Idiano D'Adamo and Frede Blaabjerg

Received: 16 April 2021

Accepted: 9 June 2021

Published: 9 June 2021

Publisher's Note: MDPI stays neutral with regard to jurisdictional claims in published maps and institutional affiliations.

\begin{abstract}
This article analyses the business community in Poland and their views on climate change and the objectives of the European Green Deal (EGD). The authors focus on the analysis of the attitude of entrepreneurs towards the cultural and ideological stereotypes promoted by climate denialists. This article shows that the ideological factor may play a certain role in shaping the attitudes of entrepreneurs towards energy transition. The research was carried out on a sample of 400 entrepreneurs. The research results indicate that the ideological factor is of particular importance among entrepreneurs who are concerned about the costs of energy transition and the expenditure related to the implementation of the EGD for economic reasons. According to the authors, the stereotypes promoted by climate sceptics may find fertile ground, particularly when accompanied by fears of additional financial costs. Attitudes towards the goals of energy transition among entrepreneurs usually differ depending on the size of the company: representatives of smaller companies, who have greater concerns about their economic position, are more likely to present the views of climate sceptics. Acceptance for the theory of climate sceptics may also be influenced by the industry sector: those who may lose out on energy transition, such as representatives of the mining industry, may share the myths of climate denialists.
\end{abstract}

Keywords: entrepreneurs; climate scepticism; European green deal; renewable energy; ideology

\section{Introduction}

Achieving the goals of the European Green Deal (EGD) and climate neutrality by the countries of the European Union (EU) by 2050 requires the engagement of states and governments and, above all, of the various sectors of civil society, individual and business prosumers, local and civic associations involved in the development of civic energy, as well as local authorities and entrepreneurs. In this sense, legal acts and resolutions adopted by the EU and its member states and additional financial outlays are not sufficient, and the bottom-up involvement of various social actors is required. Namely, energy transition is not only a financial or legal challenge [1], nor is it only a technological question. Just as the process of gaining acceptance for renewable energy takes place in various spheres of public life, the implementation and creation of renewable energy and the green transition to the EGD must be linked to democratic processes and legitimised by various civil society actors [2]. As regards acceptance for renewable energy, the three main elements of this process are indicated: market acceptance (concerns the investors and project developers, energy suppliers, utilities and grid owners, as well as all kinds of consumers), socio-political acceptance (concerns the opinion of the respective energy technology as an acceptable and useful technology and the tone of the debate in the media, politics and national institutions), community acceptance concerns the opinion of the people living in the 
surroundings of specific energy infrastructure projects and therefore bearing most of the direct external impacts of those projects [3]. Each of these areas of impact on the acceptance process is conditioned by various social factors-not only economic, but also political, cultural, ideological, axiological and epistemological ones. Moreover, it can be assumed that, depending on a specific social group, various factors and motives may dominate in shaping attitudes towards renewable energy and energy transition. For example, in the case of consumers, these may be the prices of electricity bills and concerns about them increasing, on the one hand, and beliefs about climate change and the need to take action to protect the environment, on the other. As regards entrepreneurs, in addition to calculations on electricity prices and potential investment costs, social pressure [4] and care for a company's image in the social environment may be equally important elements in shaping attitudes towards energy saving and investments in renewable energy [5]. The internal differentiation of individual social environments (consumers, entrepreneurs, employees, politicians at local and national levels, residents of specific regions) results in a multitude of different models of attitudes towards energy transition.

Additionally, each of these spheres (market, socio-political, community and cultural) can influence attitudes and orientations at various levels (local, national, global). However, these levels are not isolated, but interact with each other. As Yann Fournis and José Fortin write, each of these levels shapes a social dimension that is as important as the technology itself in implementing energy transition: the micro-social level, which targets the coordination, social interpretation, attitudes and perceptions in a local community context; the meso-political level, which addresses the multi-level governance of renewable energy projects; and the macro-economic level, which is situated between the diverse national configurations and globalisation of economic development [6].

Social actors at each of these levels have different interests, political beliefs, belong to different social classes, and represent various sectors (professional, business, cultural, spatial) of society. Hence, it is worth recalling and emphasising that energy transition is not only the replacement of one energy generation technology by another, but a complex social process affecting not only the natural environment, but also production models, employment structure, safety and workplace costs [7], international political alliances and geopolitical systems [8], power systems and relations [9], the strategies of entrepreneurs [10], the lifestyle and consumption behaviour of citizens [11,12] and dozens of other dimensions of social life. These diverse factors-including, primarily, geopolitical risk and international uncertainty [13] - may not only be affected by energy transition, but may themselves accelerate or delay the transition to renewable energy.

From the sociological perspective, energy transition and decarbonisation, in short, should be treated not only as the transition of the economy to other energy sources, but as a comprehensive change of the social system [14] and the environment in which entire societies live and work. Therefore, it is worth getting to know the effects of this process and also the current attitudes of individual groups towards the impending changes.

In the case of entrepreneurs, in addition to acceptance for energy transition, many studies focus on the economic amount that an entrepreneur or consumer is prepared to pay for further expansion of RES in their area of residence, which is defined as willingness to pay (WTP) [15]. However, if business owners are ready to use renewable energy or invest in renewable energy, in addition to economic factors-which are most often discussed in the literature-cultural and ideological issues are also important, contrary to popular belief.

This article analyses the business community in Poland and their views on climate change and the objectives of the EGD. It has been pointed out in the literature that the attitudes of entrepreneurs towards the development of renewable energy may be influenced by various factors: political, economic and physical conditions, such as access to natural resources (for example, adequate insolation or winds in a given region) [16].

In our analysis, we are particularly interested in the attitude of entrepreneurs towards the cultural and ideological stereotypes promoted by climate denialists. We recognise climate scepticism as an important determinant of attitude-not only in certain politi- 
cal environments, but also among social groups and categories distinguished based on other criteria (such as profession or class) - towards renewable energy. The attitudes of entrepreneurs in this matter are important because they are not only an expression of their ideological and cultural orientations, but also translate into specific business decisions.

Hence, the aim of this article is to emphasise the importance of ideology as a factor whose impact is not always appreciated by entrepreneurs in the analysis of investment decisions in renewable energy. Although the decision to become a business prosumer is usually determined by economic considerations, it is not indifferent to cultural and ideological issues: climate scepticism or dislike for the EU's environmental policy may play a significant role in some economic sectors. The article tries to fill the gap in studies on the attitudes of entrepreneurs towards energy transition and explain how ideological factors can translate into business decisions regarding renewable energy.

\section{Climate Scepticism, Populism and Counter-Enlightenment: Brakes to the Development of Renewable Energy and Environmental Politics}

Right-wing populists in various countries have contested the EU's climate policy. Analyses of the links between nationalism, climate scepticism, the ideology of right-wing populists and their impact on public opinion about climate and fossil fuel taxes have already been described [17]. However, there is no analysis about how climate scepticism and the aversion to energy transition promoted by right-wing populists translate into the opinions of representatives of various sectors and social groups. For example, the relationship between the propaganda of climate sceptics and entrepreneurs' views on energy transition has not been studied. On the one hand, it can be assumed that the logic of economic gains and losses should be immune to the anti-scientist ideologies and prejudices of right-wing populists, but, on the other hand, the presence of populists in the political mainstream or in power may influence the attitudes and views of entrepreneurs. Moreover, the countries in which populists took power have been implementing the populist economic programme in an attempt to give capital a national colour: East European populists "have sought to develop a national capitalist class, while balancing reliance on Western capital through closer economic relations with authoritarian countries" [18]. Public policy may limit the innovativeness of companies and perpetuate more conservative attitudes among entrepreneurs, which in turn may limit the development of renewable energy [19].

How has the relationship between right-wing populists and climate and energy issues been explained in the literature? Matthew Lockwood has described two approaches in portraying the relationship between right-wing populism and climate policy [20]. First, he has emphasised the importance of the ideological dimension in which conservative and nationalist values stand in opposition to the globalised discourse on climate change. Populists identify this discourse with the cosmopolitan and liberal elite who threaten national values and want to impose their agenda on "ordinary people". In this context, they also promote the thesis about corrupt ecologists and scientists [20]. It is a manifestation of a broader institutional distrust syndrome, which goes hand in hand with climate change denial and is an element of the conspiratorial visions of the world [21]. Overall, climate scepticism correlates with pseudoscientific beliefs [22]. Hence, climate change denial is often shared by the far right along with anti-vaccination attitudes and the belief that science is a means to manipulate and control society [23]. From this perspective, climate scepticism is just another manifestation of the typical populist right-wing distrust in and hostility towards science, and an anti-intellectual attitude [24]. The rejection of scientific knowledge about the climate and disputes with populists about related energy challenges are an illustration of the contemporary conflict between the Enlightenment and the counterEnlightenment: from this perspective, the dispute over the Enlightenment is not only the domain of historical debate [25], but can also be an element of contemporary disputes about the framework of democracy, energy policy and ecology [26].

In this trend of cultural explanations of climate scepticism and the hesitant approach to the need to implement energy transition, an important role is played by supranational institutions (such as the EU), which, from the point of view of populists, not only threaten 
national sovereignty, but also undermine traditions, national values and pose a threat to the traditional family, religion and national identity. These prejudices are often nationalistic and homophobic [27] — this theme of the EU threatening the traditional family and conservative values is common in Eastern European countries [28]. In the view of right-wing nationalists, a similar function can be performed by the issue of energy transition: the energy and climate policy promoted by the EU may be perceived as interfering in the internal affairs of a country, and market calculations in relation to energy are replaced by the ideology of defence of energy security and sovereignty [29]. In Poland, this message is amplified by the pro-government media resistant to both the EU and EU climate policy [30].

Another way to explain populist attitudes is the structuralist approach [20] that emphasises the significance of the phenomenon of the marginalisation of entire social groups and classes in the process of economic transformations, economic globalisation and changes in the labour market. From this perspective, the "losers" from modern capitalism (workers, precarious workers, residents of provinces and areas offering poorer working conditions) are more likely to seek support from right-wing populists. This line of analysis points to the shift of the working class towards populists which has been observed in different countries [31,32]. The process of the infiltration of workers by the far right intensified after the global economic crisis in 2008 [33] and has reinforced the trends that have led to the strong political influence of right-wing populism in much of Eastern Europe more than 30 years after the fall of the Berlin Wall [34]. Due to the right-wing populist shift in the former communist countries, the common EU energy and climate policy was opposed in the European Parliament primarily by Eastern European countries [35].

In turn, the weak resources of civic democracy, corruption of local political elites, dislike for EU institutions and a low level of social trust [36] make any bottom-up transformations difficult and strengthen conspiratorial thinking in Eastern Europe. The clash between traditional thinking about mining and the neo-liberal reforms that affected the post-communist economy [37] after the fall of the Eastern bloc and awakened the demons of nationalism [38] leaves little room for the social and civic face of energy transition. This is particularly evident in countries where populist governments want to keep the state monopoly on energy and energy infrastructure, as is the case in Poland and Hungary [39].

In Poland, the economic losers from the neo-liberal transformation may fear energy transition as both workers (particularly those threatened by the closure of coal mines in coal regions) and as consumers fearing increases in electricity prices. The argument that "liberal elites" will raise energy prices to the detriment of "ordinary people" is repeated quite often by right-wing populists in debates on energy transition [20,40].

Do the same factors influence the attitudes of entrepreneurs? Fear of higher energy prices can stimulate investment in renewable energy, but it can also force current savings and thus reduce investment in innovative solutions and new technologies [41]. In the cultural dimension, studies have shown that higher education and better economic position are conducive to openness to environmental politics [42]. In the political and ideological dimension, the assumptions of energy transition in Poland can gain the support of residents of large cities, people with a liberal-left-wing orientation and a less religious and secular orientation [43]. Hence, better-educated women, who more often also have left-liberal political views, support environmental politics and energy transition more than men in Poland [44].

How do the ideological factor and myths disseminated by climate sceptics and political populists translate into entrepreneurs' attitudes towards energy policy?

\section{Ideological and Cultural Determinants of Entrepreneurs' Attitudes towards Renewable Energy}

The activity of entrepreneurs is not only an economic, but, above all, a social phenomenon [45]. Where governments or states fail to cope with the introduction of new technologies and the cultural and technological challenges, social entrepreneurs can be a key force in the implementation of these tasks [46]. This also applies to investments in renewable energy. 
From the psychological perspective, specific types of personality and leadership profiles among entrepreneurs are identified that favour the implementation of energy transition in companies [47]. However, social factors influencing entrepreneurs' decisions regarding investments in renewable energy go beyond personality factors. From the sociocultural perspective, the preferred model of management culture, the level and profile of entrepreneurs' education, as well as their knowledge about environmental threats and ideological beliefs about environmental policy are more important for the energy policy implemented in a company [48].

Regarding entrepreneurs' approach to sustainable development and their attitudes towards renewable energy, ideological orientations towards environmental challenges are an underestimated element. Explaining entrepreneurs' attitudes by taking account of their political ideology can make it easier to understand their choices and motives [49]. Namely, ideology organises individuals' values and beliefs and helps explain goals, motives and justifications for the actions taken. In the case of entrepreneurs, the ideological element may be as important as the economic calculations.

So far, the impact of ideologies on national energy policy has been shown [50], the influence of ideology on legislation related to energy transition has been analysed [51], and the ideological motivations of citizens who support policies in the field of renewable energy [52] and energy efficiency have been indicated [53]. It has also been shown how the ideological colouring of the government and the model of governance influence the promotion and implementation of renewable energy [54]. So far, however, little attention has been paid to the attitudes of entrepreneurs towards the ideologies and stereotypes advocated by climate denialists. This aspect is particularly important when official government policy is sceptical of energy transition and climate challenges, as is the case in Poland under the rule of right-wing populists. To what extent can climate scepticism translate into the attitudes of entrepreneurs?

\section{Research Methods}

The survey was conducted in October 2020 using the computer-assisted telephone interviewing (CATI) technique on a sample of 400 people. The surveyed population consisted of representatives of companies operating in Poland and employing at least ten people. The respondents were representatives of these companies-people who were responsible for activities and development plans related to investing in energy efficiency (managerial staff, owners or co-owners in smaller companies). There was one respondent for each company.

The research sample was selected using the proportionate random stratified sampling procedure without return. For this purpose, the following layers were distinguished according to the following parameters: the company size (four layers), the industry (20 layers) and the province (16 layers).

The sampling frame was the BISNODE database as it ensures even territorial coverage of the country (individual provinces and city size categories). Individual records of the database contain company descriptions, taking account of their industries and size measured by the number of employees and location.

The statistical significance of the differences between the percentages for the individual groups of respondents and the result for all respondents was checked with the z-test (proportion test). The significance of differences was set at the significance level of 0.95 . The results of high static significance are shown in the tables in bold.

\section{Entrepreneurs and Energy Transition in Poland: Research Results and Discussion \\ 5.1. Global Warming as a Business: The Reception of Conspiracy Theories by Entrepreneurs}

Populists and climate sceptics often try to find connections between business and social campaigns warning about the consequences of climate change. It is a constant element of undermining the credibility of the environmental and climate movements depicted as lobbying tools for the renewable energy business. For this reason, the right- 
wing media in Poland often present environmentalists and their organisations as driven only by profit and the will to win grants [55]. The climate threat is shown as an element of propaganda, which serves to strengthen foreign companies at the expense of domestic ones from the sector based on coal and other fossil sources in the energy market. How does this message affect the opinions of entrepreneurs in Poland? Almost $60 \%$ reject these stereotypes, but as many as $37 \%$ of entrepreneurs agree with the opinion that "information about the so-called global warming is all about business-certain groups earn a lot of money by making people fear or feel guilty" (Table 1).

It is interesting, but not surprising, that the largest number of supporters of conspiracy theories about climate change is in the mining and energy sectors (47\%), which are mostly based on mined resources in Poland. This result is confirmed by the research findings among employees of the Bełchatów lignite power plant, which is responsible for releasing over 30 million tonnes of $\mathrm{CO}_{2}$ into the atmosphere (which corresponds to approximately $10 \%$ of emissions in Poland; in 2020, the Bełchatów power plant was the largest emitter in Europe) [56] (p. 8). Climate change, $\mathrm{CO}_{2}$ emissions and environmental pollution are "nonsense", according to power plant workers. The employees of the Bełchatów power plant point out that, in their opinion, the old EU countries can open new power plants, and that Poland is requested to abandon coal. These arguments echo the nationalist narrative and conspiracy theories about the financing of environmentalists by the West:

"Environmentalists very much want to close this plant. However, environmentalists there are paid by the West and they say such stupid things ... our authorities are too delicate, they are afraid that the West will criticise us. Let them criticise-this is our country, we have our Constitution, we are doing our job" [56] (p. 49).

According to the authors of the analysis, populism and climate denying among the workers and residents of Bełchatów are largely conditioned by local fears for the social and economic collapse of the town and the region, which may occur after the closure of the mine.

If economic pressure has such a strong influence on the beliefs of workers in regions dependent on the extractive industries, what is the impact of economic factors on entrepreneurs? It can be assumed that the smaller the financial potential of the company, the greater the fear about energy transition and the tendency to ideological negations of the need to protect the climate.

The results obtained have confirmed these assumptions. Namely, the managers of the smallest companies most often questioned the sense of energy transition. These data are in line with Marian Mazzucato's reflections that small companies-contrary to stereotypical opinions that they are the most innovative and open to change-present the most conservative attitudes in practice [57]. In our survey, representatives of small companies had the greatest inclination to accept the view that the slogans of global warming serve the EU core countries to promote their own companies related to renewable energy. This opinion was expressed by $30 \%$ of entrepreneurs from small companies employing from 10 to 49 people. Moreover, $64 \%$ of small entrepreneurs were of the opposite opinion. The relationship between the rejection of views on global warming and the size of the company was linear-the larger the company, the fewer prejudices against information about global warming (in companies employing more than 250 people, the percentage of people responsible for the development of the company who rejected conspiratorial opinions about global warming increased to $74 \%$ ) (Table 2). 
Table 1. Information about the so-called global warming is all about business—certain groups earn a lot of money by making people feel fear or guilt (in percentage points).

\begin{tabular}{|c|c|c|c|c|c|c|c|c|c|c|c|c|c|}
\hline & \multicolumn{5}{|c|}{ Workforce: } & \multicolumn{8}{|c|}{ Industry: } \\
\hline & Total & $\begin{array}{c}\text { From } 10 \text { to } 49 \\
\text { Employees }\end{array}$ & $\begin{array}{c}\text { From } 50 \text { to } \\
149 \\
\text { Employees }\end{array}$ & $\begin{array}{c}\text { From } 150 \text { to } \\
249 \\
\text { Employees }\end{array}$ & $\begin{array}{l}250 \text { and More } \\
\text { Employees }\end{array}$ & Agriculture & $\begin{array}{c}\text { Mining } \\
\text { /Industry/ } \\
\text { Power } \\
\text { Generation/ } \\
\text { Communal } \\
\text { Services }\end{array}$ & Construction & Trade & $\begin{array}{l}\text { Accommodation } \\
\text { and Catering } \\
\text { Services }\end{array}$ & $\begin{array}{c}\text { Services/ } \\
\text { Transport } \\
\text { and } \\
\text { Warehouse } \\
\text { Management }\end{array}$ & $\begin{array}{c}\text { Public } \\
\text { Administra- } \\
\text { tion/Education/ } \\
\text { Health- } \\
\text { care/Culture }\end{array}$ & Other \\
\hline Yes & 37 & 38 & 37 & 41 & 27 & 35 & $47+$ & 32 & 32 & 37 & 32 & 40 & 14 \\
\hline No & 59 & 59 & 59 & 59 & 69 & 56 & $49-$ & 68 & 65 & 54 & 62 & 60 & 86 \\
\hline $\begin{array}{l}\text { I don't know/hard to } \\
\text { say }\end{array}$ & 4 & 4 & 4 & - & 5 & 10 & 4 & - & 2 & 9 & 6 & - & - \\
\hline
\end{tabular}

The significance of differences was set at the significance level of 0.95 . The results of high statistical significance are shown in the table in bold.

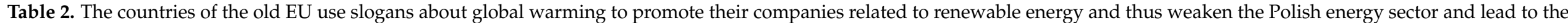
collapse of Polish mines (in percentage points).

\begin{tabular}{|c|c|c|c|c|c|c|c|c|c|c|c|}
\hline & \multicolumn{5}{|c|}{ Workforce: } & \multicolumn{6}{|c|}{ What Is the Form of Ownership of Your Company? } \\
\hline & Total & $\begin{array}{l}\text { From } 10 \text { to } 49 \\
\text { Employees }\end{array}$ & $\begin{array}{l}\text { From } 50 \text { to } 149 \\
\text { Employees }\end{array}$ & $\begin{array}{l}\text { From } 150 \text { to } 249 \\
\text { Employees }\end{array}$ & $\begin{array}{l}250 \text { and More } \\
\text { Employees }\end{array}$ & $\begin{array}{c}\text { State } \\
\text { Ownership (e.g., } \\
\text { State-owned } \\
\text { Company) }\end{array}$ & $\begin{array}{l}\text { Communal } \\
\text { Ownership } \\
\text { (Local } \\
\text { Government- } \\
\text { Owned } \\
\text { Company) }\end{array}$ & $\begin{array}{c}\text { Mixed } \\
\text { Ownership } \\
\text { with Majority } \\
\text { Capital of } \\
\text { State-Owned } \\
\text { entities }\end{array}$ & $\begin{array}{c}\text { Domestic } \\
\text { Private Property }\end{array}$ & $\begin{array}{c}\text { Foreign Private } \\
\text { Property }\end{array}$ & $\begin{array}{c}\text { Mixed } \\
\text { Ownership } \\
\text { with a } \\
\text { Predominance } \\
\text { of Private } \\
\text { Capital }\end{array}$ \\
\hline Yes & 30 & 30 & 29 & 25 & 26 & 54 & 30 & 28 & 28 & 24 & 38 \\
\hline No & 66 & 64 & 67 & 72 & 74 & 46 & 70 & 72 & 67 & 72 & 58 \\
\hline I don't know / hard to say & 5 & 6 & 3 & 3 & - & - & - & - & 5 & 4 & 4 \\
\hline
\end{tabular}




\subsection{Climate Denialism and the Opinions of Entrepreneurs in Poland}

However, as many as $42 \%$ of all surveyed entrepreneurs agreed with the view that "the natural causes that have always occurred on Earth are primarily responsible for climate change" (Figure 1). This result differed from the average for the entire population of Polish society-over the past five years, an average of approximately $20 \%$ of respondents shared this view in Poland [58]. Although experiencing extreme weather phenomena (summer heat, warm winters) is generally conducive to recognising the existence of global warming [59], it does not always imply changes in thinking and preventive actions in the energy sector. The perception of climate phenomena is often influenced by political views and the social position of individual people. On the other hand, extreme weather changes can also affect people's values and social attitudes [60].

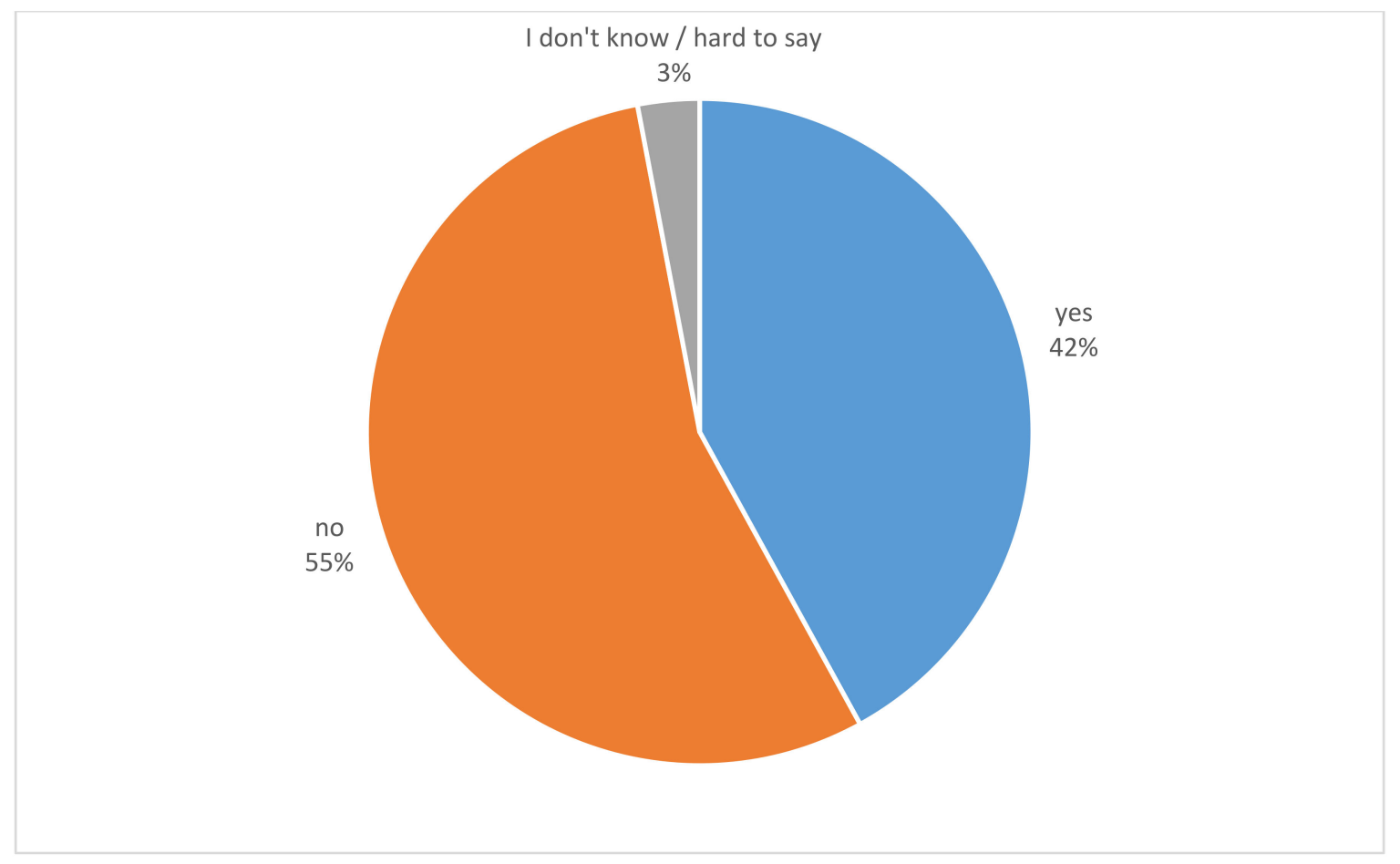

Figure 1. The natural causes that have always occurred on Earth are primarily responsible for climate change.

It is worth noting, however, that, although objective temperature changes are an indicator of global warming, their interpretation and perception may be politically and ideologically conditioned. The perception of local weather conditions does not depend on the temperature itself, but on the ideological superstructure, which dictates the method of assessing and interpreting objective phenomena [61].

How do entrepreneurs evaluate changes in temperature? Can the perception of climate change be related to one's own interests and professional activity?

Although the vast majority $(71 \%)$ of the surveyed entrepreneurs rejected the opinion that "increasing temperature in Poland is nothing terrible, as, thanks to this, we have mild winters and sunny summers", the position in the economy sector determines the perception of temperature changes. While in the entire surveyed sample, $27 \%$ of respondents did not mind the increase in temperature in Poland, in the agricultural sector, this amounted to $31 \%$, and, in the sector related to accommodation, hotel and catering services, this increased to $37 \%$ (Table 3). This shows that, like among employees of coal basins, among entrepreneurs and in sectors other than the mining industry, economic interests may also have a large impact on beliefs about climate change. Higher air temperatures and a longer growing season for plants contributed to the fact that the opinions about global warming among representatives of the agricultural sector slightly differed from the average obtained in the 
entire sample of entrepreneurs. The attitude of the hotel and catering service sector can be similarly explained. Namely, in the opinion of some representatives of this environment, the increase in temperature may serve their interests as the tourist season will be longer. From this perspective, the views on climate change and the attitude to energy transition seem to be an ideological justification of one's own economic interests related to a specific business. In Marx's language: the ideological superstructure covers the economic base, and self-interest benefits from the ideology that denies climate change.

\subsection{Economic Nationalism and Threats to the European Green Deal}

Economic nationalism can perform a similar ideological function to support individual businesses. It makes it possible to dismiss supranational actions for climate protection as "cosmopolitan" and contrary to the "national interest". While this concept may seem anachronistic in today's globalised world, the 2008 global financial crisis and the revival of nationalist movements have made it re-emerge in the mainstream economic and political debate. Economic nationalism has gained importance in economic policy [62], on the one hand, under the influence of the populist arguments of the extreme right in the public debate and, on the other hand, under the influence of concerns about the unpredictability of world markets and the effects of globalisation on national economies [63]. In the United States, the concept of economic nationalism was revived during the presidency of Donald Trump [64], who promoted isolationism and accused international trade of the reduction in local jobs [65]. Influenced by concerns about international economic competition, this concept also gained a boost in Europe [66], being the main element of the Brexit disputes and conflicts in the United Kingdom [67].

However, nationalism has also influenced debates on climate [68], resources policy [69] and energy security issues. It is in the context of the "energy security" slogan that economic nationalism develops in the form of "energy securitization" - a process where governments frame energy as an existential threat to state interests. This phenomenon occurs in states where energy issues are implicated in economic and regime security and leads governments to adopt nationalistic policy frameworks [70]. Economic nationalism in energy policy and in the management of natural resources may manifest itself in the state's full control over mining and strict regulations on foreign companies [71]. However, it can also privilege and subsidise the domestic mining industry, as is the case in Poland, where coalitions of coal corporations, trade unions, the government and some local authorities are formed to defend coal mining [72].

The results obtained indicate that nearly half (43\%) of the surveyed entrepreneurs, in the context of energy policy, accept the view that "Poland as a country should think primarily about its national economic interest and not succumb to international pressure on this matter" (Figure 2). This manifestation of economic nationalism can, however, also be an expression of fear for one's own economic interests. Namely, most of the surveyed entrepreneurs (52\%) consider the EU plans to reduce $\mathrm{CO}_{2}$ to zero and the activities related to the EGD "too expensive for countries such as Poland" (Table 4).

In Poland, the EGD arouses the greatest fears among entrepreneurs employing 50 to 149 people (63\%) (only $22 \%$ of this category of companies are not concerned)-these are statistically significant results. The goal of zero $\mathrm{CO}_{2}$ emissions is the least worrying to entrepreneurs from the largest companies with more than 250 employees (41\%). However, even in this category, only 31\% reject the view that the EGD is too expensive. It is worth emphasising that entrepreneurs from the local government sector (86\%) are most concerned about the financial costs associated with the implementation of the EGD. This is probably due to the budget deficit and financial problems faced by local government authorities in Poland as a result of the COVID-19 pandemic. Representatives of foreign private companies were least worried about financial challenges related to $\mathrm{CO}_{2}$ reduction (37\%) (Table 4). 
Table 3. Increasing temperature in Poland is nothing terrible as, thanks to this, we have mild winters and sunny summers (in percentage points).

\begin{tabular}{|c|c|c|c|c|c|c|c|c|c|c|c|c|c|}
\hline & \multicolumn{5}{|c|}{ Workforce: } & \multicolumn{8}{|c|}{ Industry: } \\
\hline & Total & $\begin{array}{c}\text { From } 10 \text { to } 49 \\
\text { Employees }\end{array}$ & $\begin{array}{l}\text { From } 50 \text { to } \\
149 \\
\text { Employees }\end{array}$ & $\begin{array}{l}\text { From } 150 \text { to } \\
249 \\
\text { Employees }\end{array}$ & $\begin{array}{l}250 \text { and More } \\
\text { Employees }\end{array}$ & Agriculture & $\begin{array}{c}\text { Mining// } \\
\text { Industry/ } \\
\text { Power } \\
\text { Generation } \\
\text { /Communal } \\
\text { Services }\end{array}$ & Construction & Trade & $\begin{array}{l}\text { Accommodation } \\
\text { and Catering } \\
\text { Services }\end{array}$ & $\begin{array}{c}\text { Services/ } \\
\text { Transport } \\
\text { and } \\
\text { Warehouse } \\
\text { Management }\end{array}$ & $\begin{array}{c}\text { Public } \\
\text { Administra- } \\
\text { tion/Education/ } \\
\text { Healthcare } \\
\text { /Culture }\end{array}$ & Other \\
\hline Yes & 27 & 29 & 25 & 17 & 22 & 31 & 28 & 29 & 29 & 36 & 22 & 16 & 13 \\
\hline No & 71 & 69 & 73 & 80 & 67 & 69 & 68 & 71 & 71 & 54 & 74 & 84 & 87 \\
\hline $\begin{array}{l}\text { I don't } \\
\text { know } / \text { hard } \\
\text { to say }\end{array}$ & 3 & 2 & 2 & 3 & 11 & - & 4 & - & - & 9 & 4 & - & - \\
\hline
\end{tabular}

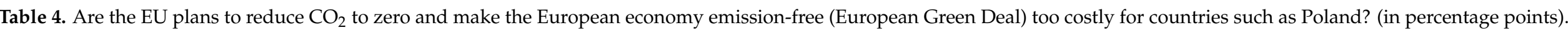

\begin{tabular}{|c|c|c|c|c|c|c|c|c|c|c|c|}
\hline & \multirow[b]{2}{*}{ Total } & \multicolumn{4}{|c|}{ Workforce: } & \multicolumn{6}{|c|}{ What Is the Form of Ownership of Your Company? } \\
\hline & & $\begin{array}{c}\text { From } 10 \text { to } 49 \\
\text { Employees }\end{array}$ & $\begin{array}{l}\text { From } 50 \text { to } 149 \\
\text { Employees }\end{array}$ & $\begin{array}{l}\text { From } 150 \text { to } 249 \\
\text { Employees }\end{array}$ & $\begin{array}{l}250 \text { and More } \\
\text { Employees }\end{array}$ & $\begin{array}{c}\text { State } \\
\text { Ownership (e.g., } \\
\text { State-Owned } \\
\text { Company) }\end{array}$ & $\begin{array}{c}\text { Communal } \\
\text { Ownership } \\
\text { (Local } \\
\text { Government- } \\
\text { Owned } \\
\text { Company) }\end{array}$ & $\begin{array}{c}\text { Mixed } \\
\text { Ownership } \\
\text { with Majority } \\
\text { Capital of } \\
\text { State-Owned } \\
\text { Entities }\end{array}$ & $\begin{array}{c}\text { Domestic } \\
\text { Private Property }\end{array}$ & $\begin{array}{c}\text { Foreign Private } \\
\text { Property }\end{array}$ & $\begin{array}{c}\text { Mixed } \\
\text { Ownership } \\
\text { with a } \\
\text { Predominance } \\
\text { of Private } \\
\text { Capital }\end{array}$ \\
\hline Yes & 52 & 49 & $63+$ & 51 & 41 & 38 & $86+$ & 100 & 49 & 37 & 68 \\
\hline No & 31 & 32 & $22-$ & 40 & 31 & 52 & $8-$ & - & 32 & 43 & 23 \\
\hline $\begin{array}{l}\text { I don't know } \\
\text { /hard to say }\end{array}$ & 2 & 3 & 1 & - & - & - & - & - & $3+$ & - & - \\
\hline
\end{tabular}

The significance of differences was set at the significance level of 0.95 . The results of high statistical significance are shown in the table in bold. 


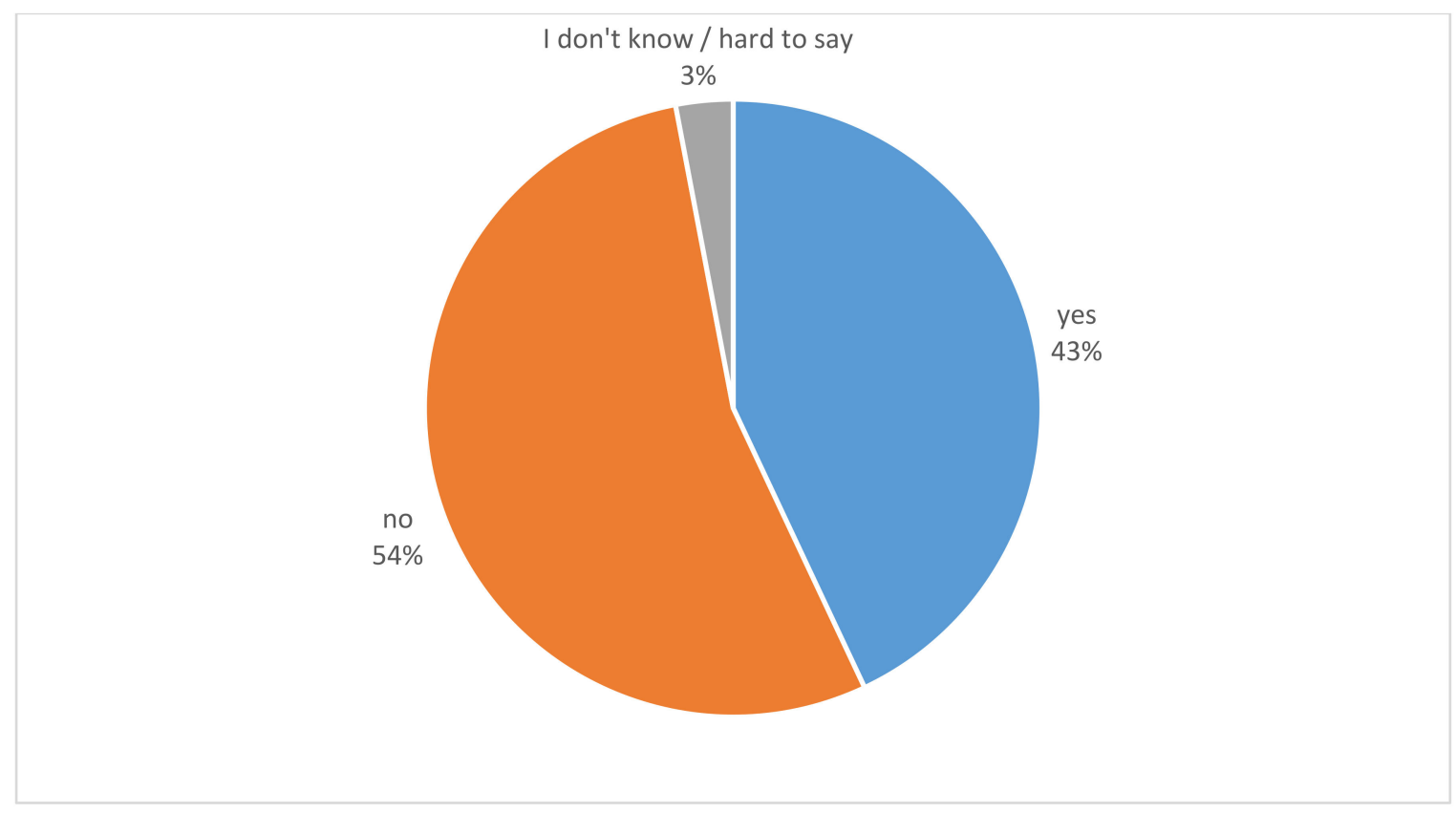

Figure 2. In the context of slogans about changes in energy policy, Poland as a country should think primarily about its national economic interest and not succumb to international pressure on this matter.

The economic interests of individual industries also influenced the choice of strategy for action in relation to climate change. While in the entire surveyed sample, 33\% of entrepreneurs indicated that "the problem of climate change should be dealt with, but its effects are slow, so rushing in energy policy changes should be avoided to reduce the costs of such activities", representatives of the mining and energy (36\%), hotel and catering $(47 \%)$, and agricultural (65\%) sectors presented this conservative attitude more often than the average for the whole group (Table 5).

Table 5. What should individual countries do about climate change? (in percentage points).

\begin{tabular}{|c|c|c|c|c|c|c|c|c|c|}
\hline & \multirow[b]{2}{*}{ Total } & \multicolumn{8}{|c|}{ Industry: } \\
\hline & & Agriculture & $\begin{array}{l}\text { Mining/ } \\
\text { Indus- } \\
\text { try/Power } \\
\text { Generation/ } \\
\text { Communal } \\
\text { Services }\end{array}$ & Construction & Trade & $\begin{array}{l}\text { Accommodation } \\
\text { and Catering } \\
\text { Services }\end{array}$ & $\begin{array}{l}\text { Services/ } \\
\text { Transport } \\
\text { and } \\
\text { Warehouse } \\
\text { Manage- } \\
\text { ment }\end{array}$ & $\begin{array}{l}\text { Public } \\
\text { Administra- } \\
\text { tion/Education/ } \\
\text { Health- } \\
\text { care/Culture }\end{array}$ & Other \\
\hline $\begin{array}{l}\text { As long as we are not sure that } \\
\text { climate change is indeed a } \\
\text { human-driven problem, no } \\
\text { steps involving economic costs } \\
\text { should be taken }\end{array}$ & 11 & - & 10 & 10 & 17 & - & 13 & - & 28 \\
\hline $\begin{array}{l}\text { Climate change needs to be } \\
\text { tackled but its impacts are slow, } \\
\text { so rushing in energy policy } \\
\text { changes should be avoided to } \\
\text { keep costs down }\end{array}$ & 33 & $65+$ & 36 & 27 & 30 & 47 & 32 & 23 & 14 \\
\hline $\begin{array}{l}\text { Climate change is a serious and } \\
\text { urgent problem. Appropriate } \\
\text { action must be taken } \\
\text { immediately, even if it involves } \\
\text { significant costs }\end{array}$ & 55 & 35 & 54 & 63 & 53 & 53 & 54 & 77 & 58 \\
\hline I don't know/hard to say & 0 & - & - & - & - & - & 2 & - & - \\
\hline
\end{tabular}

The significance of differences was set at the significance level of 0.95 . The results of high statistical significance are shown in the table in bold. 


\subsection{Opinions on the Demands of Ecologists and Energy Models Preferred by Entrepreneurs in Poland}

The views of representatives of individual sectors of the economy on climate change are consistent with their assessment of the activities and demands of the environmental movement. While in the entire surveyed population of entrepreneurs, $38 \%$ of respondents were concerned about the weakening position of the Polish economy in the international arena as a result of the implementation of environmentalists' demands-like in the previous questions-many more representatives of the catering and hotel sector $(47 \%)$, and, particularly the agricultural one (67\%), were sceptical about measures taken to reduce $\mathrm{CO}_{2}$. (Table 6).

Table 6. Can ecologists' demands, such as those concerning the necessity to reduce $\mathrm{CO}_{2}$, contribute to ... in Poland? (in percentage points).

\begin{tabular}{|c|c|c|c|c|c|c|c|c|c|}
\hline & \multirow[b]{2}{*}{ Total } & \multicolumn{8}{|c|}{ Industry: } \\
\hline & & Agriculture & $\begin{array}{l}\text { Mining/ } \\
\text { Industry } \\
\text { /Power } \\
\text { Generation/ } \\
\text { Communal } \\
\text { Services }\end{array}$ & Construction & Trade & $\begin{array}{l}\text { Accommodation } \\
\text { and Catering } \\
\text { Services }\end{array}$ & $\begin{array}{c}\text { Services/ } \\
\text { Transport } \\
\text { and } \\
\text { Warehouse } \\
\text { Manage- } \\
\text { ment }\end{array}$ & $\begin{array}{l}\text { Public } \\
\text { Administra- } \\
\text { tion/Education/ } \\
\text { Health- } \\
\text { care/Culture }\end{array}$ & Other \\
\hline $\begin{array}{l}\text { weakening the position of } \\
\text { the Polish economy in the } \\
\text { international arena }\end{array}$ & 38 & $67+$ & 35 & 33 & 42 & 47 & 35 & 27 & 58 \\
\hline $\begin{array}{l}\text { strengthening the position } \\
\text { of the Polish economy in } \\
\text { the international arena }\end{array}$ & 50 & $27-$ & 52 & 51 & 48 & 46 & 48 & 73 & 42 \\
\hline I don't know/hard to say & 12 & 6 & 13 & 16 & 10 & 7 & 17 & - & - \\
\hline
\end{tabular}

The significance of differences was set at the significance level of 0.95 . The results of high statistical significance are shown in the table in bold.

The results indicating that the representatives of the agricultural sector in Poland are the most sceptical of and reluctant to face the challenges of energy transition require further research and analysis among the rural population. This is important because, according to the data from 2020, 40\% of the Polish population live in rural areas in Poland [73]. However, most rural residents do not deal with agriculture, and development ideas are sought by Polish villages. In the context of energy transition, rural areas have the greatest potential and areas for the development of renewable energy (photovoltaic farms, individual and business prosumers, wind energy, energy cooperatives). In this way, rural areas can gain additional capital, increasing their economic potential and, for those people leaving agriculture, there are new employment and professional opportunities.

Generally, however, despite a certain impact of the ideology of climate sceptics on entrepreneurs in individual industries, most of them tend to lean towards renewable energy sources as a guarantee of good and rapid economic development. Firstly, they reject the coal-based energy model, just like Polish society in general. Secondly, just like in a representative sample of society, they choose hydroelectric power stations, wind and solar farms as the desired backbone of their energy system. Thirdly, they are more in favour of civic energy than the general public (private investments in photovoltaics, small wind turbines). This option was most often indicated by the surveyed entrepreneurs (as many as $93 \%$ ). Fourthly, entrepreneurs in Poland support nuclear energy more often than the general public. Although fewer than half of them indicted this solution $(46 \%)$, it was almost twice as many as in the entire Polish society (26\%) (Table 7). It is worth emphasising, however, that the nuclear power industry, which the government in Poland presents as a way of abandoning coal, has no public support. Nuclear and coal enjoy the least recognition and clearly lose in terms of social preferences to renewable energy sources. 
Table 7. Should the government invest in ... for the sake of the Polish economy and rapid economic development? (in percentage points).

\begin{tabular}{ccc}
\hline & Entrepreneurs & Polish Society \\
\hline coal power plants & 14 & 15 \\
wind farms & 86 & 75 \\
hydroelectric power stations & 87 & 63 \\
gas power plants & 52 & 29 \\
civic energy (private investments in & 93 & 61 \\
photovoltaics, small wind turbines) & & 65 \\
solar farms & 87 & 26 \\
nuclear power plants & 46 & 43 \\
small local biogas plants & 74 &
\end{tabular}

Source: CATI carried out in 2020: the samples were $n 400$ in the case of entrepreneurs and $n 1001$ in the case of Polish society.

\section{Conclusions}

This article shows that the ideological factor may play a certain role in shaping the attitudes of entrepreneurs towards energy transition. The research results obtained indicate that the ideological factor is of particular importance among entrepreneurs who are concerned about the costs of energy transition and the expenditure related to the implementation of the EGD for economic reasons. In this sense, the stereotypes promoted by climate sceptics may find fertile ground, particularly when accompanied by fears of additional financial costs. Attitudes towards the goals of energy transition among entrepreneurs usually differ depending on the size of the company (representatives of smaller companies, who have greater concerns about their economic position, are more likely to present the views of climate sceptics) and the industry sector (those who may lose out on energy transition, such as representatives of the mining industry, or those who believe that global warming may be good for their business, such as the agricultural sector, may share the myths of climate denialists). It is similar with economic nationalism: the greater the fear about the current position being threatened, the greater the inclination to use slogans about defending the "national interest" in the context of the expected expenditure related to energy transition.

Although most of the respondents from the business community are ultimately in favour of renewable energy sources as the basis of the energy system, it is clearly visible that the conditions for the efficient implementation of the EGD's goals include financial guarantees for those who are afraid of the additional expenses related to it. On the other hand, further civic education and social campaigns for climate protection and energy transition goals are necessary. Under Polish conditions, this is particularly important in rural areas, which are more conservative, willing to support populists and, at the same time, may benefit economically from the development of renewable energy.

Technological, market and legal aspects have been primarily considered in the discussions conducted so far on the development of business prosumers and their contribution to energy transition [74]. In future analyses, it is important to try to integrate these different dimensions (economic, technological, cultural and ideological) in explaining business involvement in renewable energy investments. This study also does not discuss the spatial aspect (place of business and its impact on the development of renewable energy) and the political aspect (both in the macrostructural dimension, where current political decisions of the authorities block or contribute to the development of institutional prosumers [75], but also in the dimension of individual sympathies of entrepreneurs) as factors potentially influencing the development of business prosumerism. Financial subsidies alone are not sufficient-what is important is the method of their distribution, the condition of political democracy and the level of democratic resources existing in society [76] (civic activity, knowledge of procedures, level of social trust). Obtaining such data can shed new light on the explanation of additional mechanisms influencing the development of renewable energy, as well as their relationship with the ideology of climate sceptics. Of 
course, access to knowledge and information about rapidly changing new technological opportunities certainly plays a significant role in the attitudes of entrepreneurs towards prosumer investments.

In addition to quantitative data from social surveys and economic analyses, further research on the relationship between business and renewable energy should be based on qualitative research methods that will make it possible to better understand the process of making decisions about the involvement of entrepreneurs or their refusal to participate in activities for energy transition.

Author Contributions: Conceptualization, P.Ż. (Piotr $\dot{Z} u k)$; formal analysis, P.Ż. (Piotr Żuk) and P.Ż. (Paweł Żuk); investigation, P.Ż. (Piotr Żuk) and P.Ż. (Paweł Żuk); methodology, P.Ż. (Piotr Żuk); resources, P.Ż. (Piotr Żuk); writing-original draft, P.Ż. (Piotr Żuk) and P.Ż. (Paweł Żuk); writing-review and editing, P.Ż. (Paweł Żuk). Both authors have read and agreed to the published version of the manuscript.

Funding: This research project was supported by The National Science Centre, Poland (NCN), under the grant number 2019/33/B/HS6/00139.

Conflicts of Interest: The authors declare no conflict of interest.

\section{References}

1. Sikora, A. European Green Deal-legal and financial challenges of the climate change. ERA Forum 2021, 21, 681-697. [CrossRef]

2. Pianta, M.; Lucchese, M. Rethinking the European Green Deal: An Industrial Policy for a Just Transition in Europe. Rev. Radic. Political Econ. 2020, 52, 633-641. [CrossRef]

3. Wüstenhagen, R.; Wolsink, M.; Bürer, M.J. Social acceptance of renewable energy innovation: An introduction to the concept. Energy Policy 2007, 35, 2683-2691. [CrossRef]

4. Zhang, Y.; Wei, Y.; Zhou, G. Promoting firms' energy-saving behavior: The role of institutional pressures, top management support and financial slack. Energy Policy 2018, 115, 230-238. [CrossRef]

5. Jones, G. Profits and Sustainability: A History of Green Entrepreneurship; Oxford University Press: Oxford, UK, 2017; ISBN 978-0-19870697-7.

6. Fournis, Y.; Fortin, M.-J. From social "acceptance" to social "acceptability" of wind energy projects: Towards a territorial perspective. J. Environ. Plan. Manag. 2017, 60, 1-21. [CrossRef]

7. Aldrich, M. Energy transitions and the workplace cost of carbon fuels, 1917-1940. Labour Hist. 2019, 60, 325-338. [CrossRef]

8. Vakulchuk, R.; Overland, I.; Scholten, D. Renewable energy and geopolitics: A review. Renew. Sustain. Energy Rev. 2020, 122, 109547. [CrossRef]

9. Burke, M.J.; Stephens, J.C. Political power and renewable energy futures: A critical review. Energy Res. Soc. Sci. 2018, 35, 78-93. [CrossRef]

10. Trianni, A.; Cagno, E.; Farné, S. Barriers, drivers and decision-making process for industrial energy efficiency: A broad study among manufacturing small and mediumsized enterprises. Appl. Energy 2016, 162, 1537-1551. [CrossRef]

11. Millot, A.; Doudard, R.; Le Gallic, T.; Briens, F.; Assoumou, E.; Maïzi, N. France 2072: Lifestyles at the Core of Carbon Neutrality Challenges. In Limiting Global Warming to Well Below $2{ }^{\circ} \mathrm{C}$ : Energy System Modelling and Policy Development. Lecture Notes in Energy; Giannakidis, G., Karlsson, K., Labriet, M., Gallachóir, B., Eds.; Springer: Cham, Germany, 2018; Volume 64, ISBN 978-3-319-74424-7.

12. Le Gallic, T.; Assoumou, E.; Maïzi, N. Future demand for energy services through a quantitative approach of lifestyles. Energy 2017, 141, 2613-2627. [CrossRef]

13. Sweidan, O.D. The geopolitical risk effect on the US renewable energy deployment. J. Clean. Prod. 2021, 293, 126189. [CrossRef]

14. Żuk, P. The Decarbonization of Society as a System Change. Soc. Nat. Resour. 2017, 30, 261-263. [CrossRef]

15. Ntanos, S.; Kyriakopoulos, G.; Chalikias, M.; Arabatzis, G.; Skordoulis, M. Public Perceptions and Willingness to Pay for Renewable Energy: A Case Study from Greece. Sustainability 2018, 10, 687. [CrossRef]

16. Eitan, A.; Rosen, G.; Herman, L.; Fishhendler, I. Renewable Energy Entrepreneurs: A Conceptual Framework. Energies 2020, 13, 2554. [CrossRef]

17. Kulin, J.; Johansson Sevä, I.; Dunlap, R.E. Nationalist ideology, rightwing populism, and public views about climate change in Europe. Envrion. Politics 2021, 1-24. [CrossRef]

18. Orenstein, M.A.; Bugarič, B. Work, family, fatherland: The political economy of populism in central and Eastern Europe. J. Eur. Public Policy 2020, 1-20. [CrossRef]

19. Doblinger, C.; Dowling, M.; Helm, R. An institutional perspective of public policy and network effects in the renewable energy industry: Enablers or disablers of entrepreneurial behaviour and innovation? Entrep. Reg. Dev. 2016, 28, 126-156. [CrossRef]

20. Lockwood, M. Right-wing Populism and the Climate Change Agenda: Exploring the Linkages. Environ. Politics 2018, 27, 712-732. [CrossRef] 
21. Jylhä, K.M.; Strimling, P.; Rydgren, J. Climate Change Denial among Radical Right-Wing Supporters. Sustainability 2020, $12,10226$. [CrossRef]

22. Jylhä, K.M.; Hellmer, K. Right-Wing Populism and Climate Change Denial: The Roles of Exclusionary and Anti-Egalitarian Preferences, Conservative Ideology, and Antiestablishment Attitudes. Anal. Soc. Issues Public Policy 2020, 20, 315-335. [CrossRef]

23. Żuk, P.; Żuk, P. Right-wing populism in Poland and anti-vaccine myths on YouTube: Political and cultural threats to public health. Glob. Public Health 2020, 15, 790-804. [CrossRef] [PubMed]

24. Wodak, R. Entering the "Post-shame Era": The Rise of Illiberal Democracy, Populism and Neo-authoritarianism in Europe. Glob. Discourse 2019, 9, 195-213. [CrossRef]

25. Elliott, P.A. Enlightenment, Modernity and Science, Geographies of Scientific Culture in Georgian England; I.B. Tauris: London, UK, 2010; ISBN 978-1-84885-366-9.

26. Pinker, S. Enlightenment Now: The Case for Reason Science Humanism and Progress; Viking: New York, NY, USA, 2018; ISBN 978-0525-42757-5.

27. Żuk, P.; Żuk, P. "Euro-Gomorrah and Homopropaganda": The Culture of Fear and "Rainbow Scare" in the Narrative of Rightwing Populists Media in Poland as Part of the Election Campaign to the European Parliament in 2019. Discourse Context Media 2020, 33, 100364. [CrossRef]

28. Żuk, P.; Żuk, P. “Democracy is not for Everyone": Nationalist Homophobia in Eastern Europe and Opposition to Liberal Democracy in the European Union. Communist Post-Communist Stud. 2020, 53, 1-21. [CrossRef]

29. Szulecki, K. Securitization and state encroachment on the energy sector: Politics of exception in Poland's energy governance. Energy Policy 2020, 136, 111066. [CrossRef]

30. Żuk, P.; Szulecki, K. Unpacking the Right-populist Threat to Climate Action: Poland's Pro-governmental Media on Energy Transition and Climate Change. Energy Res. Soc. Sci. 2020, 66, 101485. [CrossRef]

31. Van der Linden, M. Workers and the Radical Right. Int. Labor Work Class Hist. 2018, 93, 74-78. [CrossRef]

32. Ost, D. Workers and the Radical Right in Poland. Int. Labor Work Class Hist. 2018, 93, 113-124. [CrossRef]

33. Chowdhury, A.; Żuk, P. From crisis to crisis: Capitalism, chaos and constant unpredictability. Econ. Labour Relat. Rev. 2018, 29, 375-393. [CrossRef]

34. Żuk, P.; Toporowski, J. Capitalism after communism: The triumph of neoliberalism, nationalist reaction and waiting for the leftist wave. Econ. Labour Relat. Rev. 2020, 31, 158-171. [CrossRef]

35. Zapletalová, V.; Komínková, M. Who is fighting against the EU's energy and climate policy in the European Parliament? The contribution of the Visegrad Group. Energy Policy 2020, 139, 111326. [CrossRef]

36. Cartwright, A.; Batory, A. Monitoring committees in cohesion policy: Overseeing the distribution of structural funds in Hungary and Slovakia. J. Eur. Integr. 2012, 34, 323-340. [CrossRef]

37. Rîșteiu, N.T.; Creţan, R.; O’Brien, T. Contesting post-communist economic development: Gold extraction, local community, and rural decline in Romania. Eurasian Geogr. Econ. 2021, 1-23. [CrossRef]

38. Żuk, P.; Żuk, P. Offshoring, labour migration and neo-liberalisation: Nationalist responses and alternatives in Eastern Europe. Econ. Labour Relat. Rev. 2018, 29, 97-117. [CrossRef]

39. Szabo, J.; Fabok, M. Infrastructures and state-building: Comparing the energy politics of the European Commission with the governments of Hungary and Poland. Energy Policy 2020, 138, 111253. [CrossRef]

40. Forchtner, B.; Kroneder, A.; Wetzel, D. Being Skeptical? Exploring Far-Right Climate-Change Communication in Germany. Environ. Commun. 2018, 12, 589-604. [CrossRef]

41. Kong, D.; Yang, X.; Xu, J. Energy price and cost induced innovation: Evidence from China. Energy 2020, 192, 116586. [CrossRef]

42. Żuk, P.; Żuk, P. Environmental awareness and higher education: Differences in knowledge and the approach to ecology between students of technical sciences and the humanities in Poland. Appl. Environ. Educ. Commun. 2018, 17, 150-160. [CrossRef]

43. Żuk, P.; Żuk, P.; Pluciński, P. Coal basin in Upper Silesia and energy transition in Poland in the context of pandemic: The socio-political diversity of preferences in energy and environmental policy. Res. Policy 2021, 71, 101987. [CrossRef]

44. Żuk, P.; Pacześniak, A. Sustainable Development, Energy Transition, and Climate Challenges in the Context of Gender: The Framework of Gender Determinants of Environmental Orientation in Poland. Sustainability 2020, 12, 9214. [CrossRef]

45. Steyaert, C.; Katz, J. Reclaiming the space of entrepreneurship in society: Geographical, discursive and social dimensions. Entrep. Reg. Dev. 2004, 16, 179-196. [CrossRef]

46. Zahra, S.A.; Gedajlovic, E.; Neubaum, D.O.; Shulman, J.M. A typology of social entrepreneurs: Motives, search processes and ethical challenges. J. Bus. Ventur. 2009, 24, 519-532. [CrossRef]

47. Timmermans, J.; van der Heiden, S.; Born, M.P. Policy entrepreneurs in sustainability transitions: Their personality and leadership profiles assessed. Environ. Innov. Soc. Transit. 2014, 13, 96-108. [CrossRef]

48. Hassen, S.; Gebrehiwot, T.; Arega, T. Determinants of enterprises use of energy efficient technologies: Evidence from urban Ethiopia. Energy Policy 2018, 119, 388-395. [CrossRef]

49. Jarrodi, H.; Byrne, J.; Bureau, S. A political ideology lens on social entrepreneurship motivations. Entrep. Reg. Dev. 2019, 31, 583-604. [CrossRef]

50. Thonig, R.; Del Río, P.; Kiefer, C.; Lázaro Touza, L.; Escribano, G.; Lechón, Y.; Späth, L.; Wolf, I.; Lilliestam, J. Does ideology influence the ambition level of climate and renewable energy policy? Insights from four European countries. Energy Source Part $B$ 2021, 16, 4-22. [CrossRef] 
51. Hess, D.J.; Mai, Q.D.; Brown, K.P. Red states, green laws: Ideology and renewable energy legislation in the United States. Energy Res. Soc. Sci. 2016, 11, 19-28. [CrossRef]

52. Fobissie, E.N. The role of environmental values and political ideology on public support for renewable energy policy in Ottawa, Canada. Energy Policy 2019, 134, 110918. [CrossRef]

53. Allen Wolters, E.; Steel, B.S.; Warner, R.L. Ideology and Value Determinants of Public Support for Energy Policies in the U.S.: A Focus on Western States. Energies 2020, 13, 1890. [CrossRef]

54. Sequeira, T.N.; Santos, M.S. Renewable energy and politics: A systematic review and new evidence. J. Clean. Prod. 2018, 192, 553-568. [CrossRef]

55. Gójska-Hejke, K. Żerowisko ekologów. Gazeta Polska, 16 March 2016.

56. Dańkowska, A.; Sadura, P. Przespana Rewolucja. Sytuacja Społeczna w Regionie Bełchatowskim u Progu Transformacji Energetycznej; Krytyka Polityczna, Instytut Studiów Zaawansowanych: Warszawa, Poland, 2021; ISBN 978-83-66586-66-6.

57. Mazzucato, M. The Entrepreneurial State: Debunking Public vs. Private Sector Myths; Anthem Press: London, UK, 2013; ISBN 9780857282521.

58. CBOS. Polacy Wobec Zmian Klimatu. Komunikat z Badań; CBOS: Warszawa, Poland, 2018; No. 158. Available online: https: //www.cbos.pl/SPISKOM.POL/2018/K_158_18.PDF (accessed on 15 April 2021).

59. Shao, W. Weather, climate, politics, or God? Determinants of American public opinions toward global warming. Environ. Politics 2017, 26, 71-96. [CrossRef]

60. Cutler, M.J. Seeing and believing: The emergent nature of extreme weather perceptions. Environ. Sociol. 2015, 1, 293-303. [CrossRef]

61. Shao, W.; Goidel, K. Seeing is Believing? An Examination of Perceptions of Local Weather Conditions and Climate Change among Residents in the U.S. Gulf Coast. Risk Anal. 2016, 36, 2136-2157. [CrossRef] [PubMed]

62. Ausserladscheider, V. Beyond economic insecurity and cultural backlash: Economic nationalism and the rise of the far right. Sociol. Compass 2019, 13, e12670. [CrossRef]

63. Pryke, S. Economic Nationalism: Theory, History and Prospects. Glob. Policy 2012, 3, 281-291. [CrossRef]

64. Baltz, M.J. “Americanism not globalism will be our credo!": An analysis of the economic nationalism(s) of Trump's administration and an agenda for further research. Nations Natl. 2021, 27, 1-19. [CrossRef]

65. Schoenbaum, T.J.; Chow, D.C.K. The Peril of Economic Nationalism and a Proposed Pathway to Trade Harmony. Stanf. Law Pol. Rev. 2019, 30, 115-195. [CrossRef]

66. Colantone, I.; Stanig, P. The Trade Origins of Economic Nationalism: Import Competition and Voting Behavior in Western Europe. Am. J. Pol. Sci. 2018, 62, 936-953. [CrossRef]

67. Rioux, X.H. Rival economic nationalisms: Brexit and the Scottish independence movement compared. Can. Foreign Policy J. 2020, 26, 8-24. [CrossRef]

68. Conversi, D. The Ultimate Challenge: Nationalism and Climate Change. Natl. Pap. 2020, 48, 625-636. [CrossRef]

69. Wilson, J.D. Regionalising resource security in the Asia-Pacific: The challenge of economic nationalism. Aust. J. Int. Aff. 2015, 69, 224-245. [CrossRef]

70. Wilson, J.D. A securitisation approach to international energy politics. Energy Res. Soc. Sci. 2019, 49, 114-125. [CrossRef]

71. Fontaine, G.; Fuentes, J.L.; Narváez, I. Policy mixes against oil dependence: Resource nationalism, layering and contradictions in Ecuador's energy transition. Energy Res. Soc. Sci. 2019, 47, 56-68. [CrossRef]

72. Brauers, H.; Oei, P.-Y. The political economy of coal in Poland: Drivers and barriers for a shift away from fossil fuels. Energy Policy 2020, 144, 111621. [CrossRef]

73. Wilkin, J.; Hałasiewicz, A. (Eds.) Polska Wieś 2020. Raport o Stanie Wsi; Scholar: Warszawa, Poland, 2020; ISBN 978-83-66470-34-7.

74. Botelho, D.F.; Dias, B.H.; de Oliveira, L.W.; Soares, T.A.; Rezende, I.; Sousa, T. Innovative business models as drivers for prosumers integration-Enablers and barriers. Renew. Sustain. Energy Rev. 2021, 144, 111057. [CrossRef]

75. Campos, I.; Pontes Luz, G.; Marín-González, E.; Gährs, S.; Hall, S.; Holstenkamp, L. Regulatory challenges and opportunities for collective renewable energy prosumers in the EU. Energy Policy 2020, 138, 111212. [CrossRef]

76. Ankrah, I.; Lin, B. Renewable energy development in Ghana: Beyond potentials and commitment. Energy 2020, $198,117356$. [CrossRef] 